\title{
Factors Affecting Bank Risks in Vietnam
}

\author{
Phuong Anh Nguyen ${ }^{1,2} \&$ Thi Thuy Trang Dinh ${ }^{1,2}$ \\ ${ }^{1}$ Department of Finance and Banking, School of Business, International University, Ho Chi Minh City, Vietnam \\ ${ }^{2}$ Vietnam National University of Ho Chi Minh City, Ho Chi Minh City, Vietnam \\ Correspondence: Phuong Anh Nguyen, School of Business, International University, Quarter 6, Linh Trung Ward, \\ Thu Duc City, Ho Chi Minh City, 700000, Vietnam.
}

Received: July 10, 2021

Accepted: August 31, 2021

Online Published: September 5, 2021

doi:10.5539/ijef.v13n10p42

URL: https://doi.org/10.5539/ijef.v13n10p42

\begin{abstract}
The research identifies the determinants of credit risk and insolvency risk in the Vietnamese banking sector. Using the data sample of 25 commercial banks over ten years (2008-2017), we examine the relationship between internal variables, external variables, and bank risks. In this study, the independent variables are bank size, bank capitalization, return on asset, return on equity, loan loss provision, capital adequacy ratio, inflation rate, and GDP growth rate. In contrast, non-performing loans and Z-score are the dependent variables. The empirical results show that all factors have an effect on bank risks except liquidity ratio.
\end{abstract}

Keywords: bank risk, credit risk, insolvency risk, commercial banks, Vietnam

\section{Introduction}

There have been several financial crises worldwide such as the 1992-1993 European monetary system crisis, Mexico 1994-1995 crisis, Asian crisis 1997-1998, and the global crisis in 2008. A myriad of reasons caused the financial crisis in 2008, and the subprime mortgage was an essential factor. When the economy operates inefficiently, the interest rate increases to create a repayment burden of borrowers and increased unemployment, the risk of subprime mortgages will be affected quickly. The grave consequences and the long-term effects of the crisis have accentuated the significance of early recognizable identifying risk-related factors.

Widely known as the financial lifeline, the banking sector's operations cover economic and social activities. The main activity of the banking system is capital mobilization from the savings sector to the manufacturing sector investment. Banks collect personal savings and lend them to businesses and manufacturers. Banks conduct credit based on analysis, appraisal, and valuation of borrowers' information. Thereby, financial capital is distributed and utilized most effectively. However, the bank's operation always confronts several problems. Thus, to ensure financial stability for the bank and satisfy the customers' needs, banks must maintain the balance between demand and ability to obtain capital in major cases. Furthermore, the bank's operation characteristics have a very high leverage ratio (capital mobility is larger than the owner's equity), leading to increased risk. Therefore, bank administrators must focus on risk management to make profits and limit damage to banks.

In theory and practice, banks are prone to credit, currency, liquidity, and country risk. With unique characteristics, the bank's operation is always inherent in risk, economic decisions based on risk and profits. The higher risk may lead to more profits, but it also makes the banking system accumulate more hazards. Heffeman (2005) showed that if the risks occur frequently, banks will lose capital and profits and reduce the value of their assets, thereby affecting the bank's operation. Therefore, banks must focus on risk-related issues.

There are many reasons why banks increase risk accumulation: weak risk management, profiteering, chasing profit, etc. The global financial crisis in 2008-2009 set such a typical example, primarily caused by subprime lending and excess risk by the US banking industry.

The spillover influence of the global financial crisis is enormous on the economies of nations. Moreover, the different levels of impact will be determined by the degree of integration for each country to the global economy. Large economies such as the United States, the European Union, and Japan are directly affected by unfavourable economic growth that narrows down the manufacturing business, stagnates or bankruptcy, and increases unemployment rates. Recently, Vietnam has been integrating more profoundly into the world economy, so its economy and the financial system in particular also had to bear heavy consequences of this financial crisis. The 
global financial crisis narrows the market due to the enterprise's production reduction that causes personal income to drop sharply. Therefore, the demand for goods consumption falls and leads to a decrease in the country's GDP. It also has a significant effect on the investment and production activities of enterprises. In addition, this crisis exerts an indirect impact on financial, monetary markets and banking activities. It makes investments and contributed capital to purchase investors' shares reduced and more limited and causes fluctuations in the interest rates on gold prices and world currencies. Monetary markets worldwide with a crisis often fluctuated rapidly and continuously. All of them have several impacts on the currency market, the foreign exchange market, etc. According to the research analysis, there are several underlying roots of the financial crisis. Among the leading causes, bank risk is the most noticeable, which has been a concern by the society.

The global financial crisis is a financial epidemic in which countries around the world are affected. Vietnam is undeniably among the countries impacted on economic growth, import and export growth, etc. Agricultural exports fell sharply: rice reduction by $58 \%$, rubber decrease by $48 \%$, coffee by $24 \%$, and aquaculture by $15 \%$. From Vietnam's goods exports to imports have declined, with slower product consumption and increased inventory. Besides, it is also affected by tightening monetary policy, limiting credit growth to make higher lending interest rates, and increasing the banks' bad debts. Therefore, the government of Vietnam has issued appropriate guidelines to monitor and provide support orientations for enterprises such as promoting business cooperation, propaganda in support of domestic consumers, or control monetary policy. Bank risk has been paid more attention to the society when this is at the root of the financial crisis 2007-2008. So, Vietnam banking system during the reform process has much developed about the scale, products, and services quality, but the issue of risk does not seem to be widely recognized. Vietnamese commercial banks face many risks when the non-performing loan ratio has increased, and liquidity shortages rise and profit decline. The reasons may come from the bank's decisions, loan policy, and weak expense management or the country's economic conditions. Therefore, the need to understand more about determinants of bank risk has become essential.

This research mainly aims to focus on identifying the determinants of bank risks in Vietnamese commercial banks. We examine how bank risks are related to internal and external factors. This research investigates bank-specific variables such as bank size, capital, profitability, loan loss provisions, and asset liquidity. Moreover, the study includes regulatory variables and macroeconomic variables.

\section{Literature Review}

\subsection{Bank Risk}

There are several types of bank risks and each of them will be measured by different indexes and methods. Not only policymakers but also customers and investors worry about bank collapses, so we investigate the correlation between bank risk and the likelihood of default. It is commonly expressed through credit risk (non-performing loans) and insolvency (Z-score). Therefore, we examine and measure bank risks through Z-score and non-performing loans (NPL).

Z-score is identified as an indicator of the bank's risk forecast and overall risk measure risk in the banking sector, which is based on the results of Roy (1952). Subsequently, Hannan and Hanweck (1988) and Boyd, Graham, and Hewitt (1993) developed and formalized the use of Z-score reflecting the probability of insolvency.

Z-score is defined as below:

$$
\mathrm{Z}-\text { score }=\frac{E(\text { ROA })+\frac{\text { Equity }}{\text { Asset }}}{\sigma(R O A)}
$$

where, ROA is the earning divided by average total assets,

$\mathrm{E}(\mathrm{ROA})$ is the expected value of return on asset,

$\sigma$ is the standard deviation of return on asset,

Equity/Asset is the average equity divided by average total asset

The Z-score measure is widely used to measure the risk forecast and financial stability in the banking sector. According to Chiaramonte et al. (2016), the Z-score model is appropriate for predicting the bankruptcy of businesses. This finding indicates that the Z-score's accuracy to test the enterprise's adequate performance is 76\%. On the other hand, Zhang, Xie, Lu, and Zhang (2016) employed U.S. bank holding companies (BHCs) data with an extended period of 3 or 4 years. They suggested the bank's risk might change with bank strategy and lending patterns over a longer time frame.

Moreover, Vincent et al. (2018) applied this measure to U.S. and European banks between 2006 and 2014. They 
find that a ROA-based Z-score using current values of the capital-asset ratio is the best model for both the U.S. and Europe. Larysa (2019) also used the Z-score model to evaluate data from EU member countries and the three associated countries (Ukraine, Georgia, and Modavia) for the period 2007- 2014. The conclusion is that this is a valuable tool in measuring the financial stability of the banking sector. Higher Z-score indicates less risky and more stable banks and vice versa - the decline of this indicator signals less resistance and more vulnerability.

Gonzalez (2006) and Caprio (2007) used the non-performing loans (NPLs) ratio as a measurement of the impacts on credit risk. Delis and Kouretas (2011) illustrated that non-performing loans cause risks, damages to banks, and the higher this ratio, the higher the credit risk. Batra (2003) found that NPL affects profitability, liquidity, and competitive functioning and the psychology of bankers. Atoi (2018) also used the Z-score model to evaluate Nigerian banks with national and international operational licenses from 2014:Q2 to 2017:Q2. The results reveal that international banks withstand shocks from NPLs better than national banks in the long run. Using the data from the four major commercial banks in Namibia from 2014 to 2018, Maseke and Swartz (2020) found that in the worst period, NPLs increase while profit increases so external factors still play a major role. Non-performing loan is a vitally crucial indicator to evaluate credit risk in the banking sector. Non-performing loan is the amount of borrowing money of which debtors do not make payment interest or the principal by the specified time. The banks cannot revoke granting lending and interest. However, they still must pay the interest and principal for other deposits in due time, leading to imbalances between revenues and expenditures. The probability of not receiving pay back loans from customers is relatively high; Banks lose capital, reduce income and profit. The non-performing loan ratio is expressed as follows:

$$
\text { NPL Ratio }=\frac{\text { Non }- \text { performingloans }}{\text { Grossloans }}
$$

\subsection{Bank Specific Factors}

Lying at the heart of the countries' economies, banks are regarded as financial institutions, constantly dealing with risk and profit. Along with the benefits that banks get, they also face many hidden hazards that arise from implementation processes. Therefore, there have been several types of research about risks to provide deeper insight and explain the problem behind the banking sector. Reviewing these studies suggests some determinants that need to be investigated in the case of Vietnam. The factors affecting bank risk are divided into two main categories. The first category involves a group of risk determinants that are the specific risks for each bank. These factors consist of capitalization, size, probability, liquidity, and capital regulatory. Second, a group of determinants contain the factors associated with bank risks to the macroeconomic environment in the banking operation system, for instance, s GDP growth rate and inflation rate.

According to previous studies, bank size and risk have complex relationships. A myriad of findings show the unfavourable correlation between bank size and risk such as Hughes et al. (2001), Hu et al. (2004), Garcia-Marco and Role-Fernandez (2008), Nguyen (2011), and Mongid et al. (2012). Nguyen (2011) found that banks with larger sizes will constrain and diversify more than banks with small size because large banks have more potential, more flexibility, many product lines, and many sources to generate revenue such as cash management professional fees, and financial advice. Hu et al. (2004) found that banks with a significant asset are associated with more resources and experience to handle adverse selection problems and moral hazards. Meanwhile, smaller banks cannot solve these problems in a good way because they lack capacity and expertise to evaluate credit ratings. For this reason, a bank of small size often has higher non-performing loans than a bank of larger size.

Laeven et al. (2014) recommended that the economy of scale and economies of scope can be used to explain the relationships. Banks with large size have more advantages for operating in many market segments and different countries. This implies banks increment benefits from giving more items to progressively potential clients. In addition, the variety of activities reduce risk and allow banks to operate with minimizing risk of crisis. In some previous studies, the researchers figure out that sometimes the increase of bank size is not from the economy of scale or scope, it may come from a phenomenon of "too-big-to-fail". Kane (2010) suggested that large banks with large asset size will take more risk than banks with small dimensions. Larger banks take more risks in business decisions, higher amounts of investment and loans because they believe their banks are too big to fail.

Moreover, according to Boyd and Runkle (1993) and Demsetz and Strahan (1997), large banks may use the unnecessarily leveraged instrument to expand their assets. This leading these banks to take more risks. Babanskiy (2012) recognized that banks of major size believe the government will assist them if the economic crisis occurs. This conviction will ensure the banks' leverage to conduct more risky activities.

Capital is among the most significant elements influencing the solidity of the banking sector. It finances its 
investment or reduces the probability of bankruptcy. Previous studies considered capital as an essential variable in determining bank risk, as a financial cushion to keep away from budgetary stuns and extreme dangers. Demirguc et al. (2010) found that higher bank capital would motivate bankers to take on more risk. Fatnassi, Hasnaoui, Ftiti (2014) studied 13 banks in the GCC countries over the period (2003-2011) and identified that bank capital is positively related to risk. This finding indicates that banks will decide to invest if their capital is large enough to eliminate risky behaviours. In contrast, according to research results in the developing countries, Tan and Floros (2013), Mohamed (2015), Tu (2016) revealed highly capitalized banks are less risky. Moreover, Rim El-Khoury (2020) chose a sample of 23 Lebanese banks between 2009 and 2014 and obtained the same results of negative relationship for both listed and unlisted banks. While Haq and Heaney (2012) pointed out that capital follows the U-form relationship with bank risk, with a sample for European banks from 1996 to 2010. Thereby, these researchers believe that the relationship between capital and risk is unpredictable.

Profitability is an effective measure to appreciate the operational situations as well as the risky of the banks. There are several types of research about the relationship between profitability and bank risk. Jensen and Meckling (1976) were two of the first researchers to learn about their relationship. Their findings indicated that poor profitability banks tend to invest more in riskier activities, increasing their return. According to Martynova, Ratnovski, and Vlahu (2015), higher profitability allows banks to borrow more and accept riskier on a large scale. In the same year, Noman et al. (2015) used OLS random effect model, GLS and GMM for Bangladesh. They suggested that an increase in exposed credit risk leads to a decrease in the bank's profitability.

In contrast, Hien and Giang (2020) employed a similar method for Vietnamese data; however, the result is different: banks tend to take on more risk when facing increased profitability. With a sample of Chinese banks, Tan (2016) concluded that profitability does not interrelate with bank risk. Profitability is measured by Return on Asset (ROA) and Return on Equity (ROE). Return on Asset (ROA) is a profitability ratio, which measures a bank's profitability compared to its assets. It is defined as the ratio of net income to the average total assets. Return on Equity (ROE) is considered a variable to control effectiveness between equity management and bank risk. This ratio is a measurement of the profit the bank can earn from its shareholder investment. In the bank's strategic development, increased equity is also associated with profitability and risks.

Liquidity is a virtually vital variable to determine the financial health bank. The commercial bank's liquidity is seen as an immediate ability to meet the demand for withdrawing. Using the ratio of total liquidity over total assets makes it possible to estimate this variable, which allows identifying the relationship between liquidity and bank risk. Charya and Naqvi (2012) suggested that banks with higher liquidity tend to be riskier by declining the lending standard to increase the volume of loans. Alternatively, the findings indicate that relationships fluctuate and change over time between liquidity and bank risk. It is supported by Muhammad et al. (2017) employed data for U.S. bank holding companies from 1986 to 2014. They suggested a reduction in funding liquidity increases bank risk; however, during the Global Financial Crisis banks with lower funding liquidity take less risk. Futhermore, Nguyen and Quyen (2018) chose the sample of banks from Vietnamese commercial banks between 2002 and 2016 and concluded that there is no empirical statistical evidence to confirm a correlation between liquidity and risk-taking. The results of the relationship between liquidity and bank risk are positive such as Agenor and Aynaoui (2009), Berger and Bouwman (2009) Cao and Illing (2008) and Khan et al. (2015). Vodová (2011), Deléchat et al. (2012), Truong and Minh (2014) found that liquidity remains negatively related to credit risk.

Whalen (1988) suggested the higher the non-performing loans are, the greater the loan loss provision to gross loans ratio and the risk will be. The higher loan-loss provision means a greater credit risk of banks, an increase in non-performing loans, a decline in asset quality, and harmful effects on profit. Some researchers found the positive relation between two variables, such as Hasan and Wall (2003), Ahmad and Ariff (2007), and Chaibi and Ftiti (2015). Conversely, Halling (2007) found a negative relationship between loan loss provision and bank risk. Banks with good financial healthy take the initiative in improving provisions, and banks face financial difficulties that will reduce provision at the lowest level. Fakir (2018) analyzed 56 Bangladesh commercial banks' collected information between 2009 and 2017 and found that higher non-performing loans are higher loans loss provisions. Both variables have a negative relationship with profitability.

Homolle (2004) found that the regulation of capital requirements limits risks to protect their banks from the risk of insolvency. Lee and Chih (2013) believed that capital regulation has a beneficial effect on bank risk-taking. Aysa and Razali (2020) used the SEM method and data of 565 commercial banks from 52 countries throughout 2011-2015. Correspondingly, a good correlation between capital regulatory and risk is shown by the empirical results. On the contrary, the research of Patrick et al. (2017) disclosed that credit risk has a significant impact on profitability. A higher capital adequacy ratio records better profitability and lower bank's risk than commercial 
banks in Nigeria. Moreover, according to Adamgbo et al. (2019), capital adequacy can remarkably downward bank's risk in both short and long-run periods, using the sample date in Nigeria from 1989 to 2015. There are some recent research works that find the opposite relation between capital regulatory and risk, such as Zong-yi et al. (2008), Zhang, Wu, and Lui (2008), Agoraki et al. (2011), and Delis, Tran, and Staikouras (2011).

\subsection{Macroeconomic Factors}

Pasiouras and Kosmidou (2007) found that macroeconomic conditions affect bank profit along with their specific characteristics. Other studies of Cifter et al. (2009), Nkusu (2011) and Segoviano et al. (2006) also placed a heavy emphasis on macroeconomic determinants of NPLs.

Inflation is a macroeconomic variable, which is used to consider the level impact on risk. Due to the high inflation rate can make the low value of profitability and increased repayment of borrowers, banks choose to take more risks. In countries with a change in interest rate, the inflation rate, perhaps, is negatively linked to the ability to pay interest or payment of customers because of changes in monetary policies to combat inflations and maintain banks' profit. Gunsel (2012) and Badar and Javid (2013) found the positive effect of inflation. Following the research, Kobia (2018) also discovered the significant relationship between inflation and bank risk when using sample data of commercial banks in Kenya from 2013 to 2017. On the contrary, Poudel (2013) found that the inflation rate negatively impacts credit risk in Nepal over ten years periods. Moreover, Myra (2020) examined 120 samples of 20 Asian banks covering the period of 2012 to 2017, and the result is that profitability is still upward while inflation rate is high.

Gross Domestic Product (GDP) is considered a variable to control for macroeconomic, representing the impact of the economic cycle on the bank's operation and risk. GDP allows banks to perform better and avoids risks. Following Samir (2013), a country that has better economic growth tends to lower risk. Due to the financial crisis period and a prolonged recession, banks face several difficulties, such as customers not fulfilling their debt repayment obligations leading to increased risk for the banks. Kobia (2018) used a panel of multiple regression analysis datasets of 43 commercial banks in Kenya between 2007-2015. The findings show that the growth rate in GDP does not affect bank credit risk. In addition, Kharabsheh (2019) proposed that the growth rate in GDP and the inflation rate do not affect bank credit risk when applying a panel for commercial banks in Jordan from 2000 to 2017. While Myra (2020) showed that the relationship between real GDP growth and credit risk is undoubtedly positive and point out that inflation creates an enormous significant effect on risk, Alas and Saurina (2002), Fofack (2005) argued about the existence of a negative impact on bank's risk. On the other hand, the fluctuation influences credit risk-taking are found by Laxmi (2019).

\section{Method}

\subsection{Data and Variables}

As illustrated in previous studies, the researchers show a myriad of variables that may affect bank risk-taking. This research works towards a goal of identifying the relationships between internal factors, external factors and bank risk in the context of Vietnam banking system. We use a panel dataset for banks from 2008 to 2017.

This research focuses only on Vietnamese banks, meaning to overlook other financial institutions, including insurance companies, credit unions or investment funds. Moreover, the list of banks includes commercial banks except foreign banks and joint-venture banks. According to the State Bank of Vietnam announcement at the end of 2017, there have been 31 Vietnamese commercial banks. However, some banks are unlisted and do not have public information in the annual reports. For that reason, we collect a sample size of 25 Vietnamese commercial banks, including small, medium, and large size banks. Since the relationship between factors and bank risk will be explored and clarified during the crisis period, the period chosen for this study is from 2008 to 2017. The 2008 subprime crisis is widespread and affects almost all financial markets worldwide. However, until late 2008, the word-wide financial crisis officially started in the United States and spread worldwide. The crisis shook and devastated the global economy. In 2017 along with the world economies recovery and the highest growth rate since the financial crisis, Vietnam also has had positive changes and rehabilitate the economy.

The bank dataset used in this study is obtained from the annual report. The dataset of internal factors and risk measures are collected from both the yearly report of banks and the bank's website. The data for macroeconomic variables are collected from the World Bank database (https://www.worldbank.org). 
Table 1. Definition of selected variables

\begin{tabular}{|c|c|c|}
\hline Variables & & Description \\
\hline \multicolumn{3}{|l|}{ Dependent Variables } \\
\hline Non-performing loans & NPLs & $\begin{array}{l}\text { A nonperforming loan (NPL) is a sum of borrowed money upon which the debtor has not } \\
\text { made the scheduled payments for a specified period }\end{array}$ \\
\hline Bank Z-score & Z-score & Z-score captures the probability of default of a country's banking system \\
\hline \multicolumn{3}{|l|}{ Independent Variables } \\
\hline Bank zise & LnTA & The natural logarithm of total assets \\
\hline Bank capitalization & $\mathrm{BC}$ & $\begin{array}{l}\text { The difference between a bank's assets and its liabilities, and it represents the net worth of } \\
\text { the bank or its equity value to investors }\end{array}$ \\
\hline \multirow[t]{2}{*}{ Profitability } & ROA & An indicator showing the correlation between the profitability of a company and its assets \\
\hline & ROE & An indicator of the effectiveness of the use of equity in the banks \\
\hline Liquidity & LIQ_A & $\begin{array}{l}\text { An important class of financial metrics used to decide a debtor's capacity to take care of } \\
\text { current obligation commitments without raising outer capital }\end{array}$ \\
\hline Loan loss provision & LLPs & An expense put aside as a remittance for uncollected credits and advance installments \\
\hline Regulatory quality & CAR & $\begin{array}{l}\text { The indicator is used to set standards for banks by looking at a bank's ability to pay } \\
\text { liabilities, respond to credit risks }\end{array}$ \\
\hline \multicolumn{3}{|c|}{ Macroeconomic Variables } \\
\hline Inflation & INF & The inflation rate \\
\hline GDP growth rate & GDP & The growth rate of real GDP \\
\hline
\end{tabular}

\subsection{Research Methods}

Using a regression model with three approaches: Pooled-OLS, Fixed Effect Model (FEM) and Random Effect Model (REM) to find a suitable model in this case. The problems of multicollinearity, autocorrelation, and heteroscedasticity will be controlled in the model. If there are heteroskedasticity of residuals and autocorrelation issues, we will use regression with Driscoll-Kraay standard errors to overcome these phenomena on the panel data. We will use the Stata 14 to analyze data with Pooled OLS, Fixed Effect Model (FEM) and Random Effect Model (REM), and diagnostic tests.

\subsection{Empirical Model}

To test the determinants of bank risk, a panel data regression model is used. The empirical model consists of several variables for bank-specific and macroeconomic variables, which can affect the bank risk. Inspired by the research work of Jabra et al. (2017) and Morshedur (2018), the empirical model is given as below:

$$
\begin{gathered}
N P L S=\alpha_{0}+\alpha_{1} L n T A_{i t}+\alpha_{2} B C_{i t}+\alpha_{3} R O A_{i t}+\alpha_{4} R O E_{i t}+\alpha_{5} L I Q_{i t}+ \\
\alpha_{6} L L P_{S_{i t}}+\alpha_{7} C A R_{i t}+\alpha_{8} I N F_{t}+\alpha_{9} G D P_{t}+\varepsilon_{i t} \\
Z-\text { score }=\alpha_{0}+\alpha_{1} L n T A_{i t}+\alpha_{2} B C_{i t}+\alpha_{3} R O A_{i t}+\alpha_{4} R O E_{i t}+\alpha_{5} L I Q_{i t}+\alpha_{6} L L P_{S_{i t}}+ \\
\alpha_{7} C A R_{i t}+\alpha_{8} I N F_{t}+\alpha_{9} G D P_{t}+\varepsilon_{i t}
\end{gathered}
$$

Where $\mathrm{i}$ and $\mathrm{t}$ denote the bank and time dimension of the panel sample, respectively, $\alpha$ are constant. For the dependent variables, there are two variables to represent bank risk: non-performing loans (NPLs) and Z-score. NPLs are a proxy for the bank's credit risk, where higher values of NPLs correspond to higher bank risk. Z-score is a proxy for insolvency risk in which higher values of the Z-score represent the lower probability of bank default. Independent variables are $\ln (\mathrm{TA}), \mathrm{BC}, \mathrm{ROA}, \mathrm{ROE}, \mathrm{LIQ} \_\mathrm{A}, \mathrm{LLPs}$, and CAR as internal variables for the individual bank, and some macroeconomic variables such as INF and GDP.

\section{Results}

\subsection{Summary Statistics Data}

In this research, we have 250 bank-year observations for 25 Vietnamese commercial banks over 10 years. Table 2 reveals the summary statistics for all the variables used in this study. The average NPL is $2.3 \%$, with a standard deviation of $1.5 \%$ and hit the lowest value of $0 \%$ by Lien Viet Post Bank in 2008 and reached the highest value of $11.40 \%$ by Sai Gon Commercial Bank (SCB) in 2010. Compared to the limit set by the State Bank of Vietnam of NPL ratio target under below 3\%, almost all banks manage and improve the quality of credits and loans or have the policy to write off bad debt and change the classification of the loan. The Z-score ratio has the degree of dispersion among banks from -1.21 to 7.83 .

Moreover, the average value of the $\mathrm{Z}$-score is 1.71 , and this ratio warns banks over the crisis period to have 
financial problems that need to be considered and improved. The data description reports the average bank size of 32.11, the minimum size of the bank of 27.87 by Viet Bank in 2008, and the maximum bank size of 34.72 by BID bank in 2017. The sample includes three types of size banks: small, medium and large. The mean of ROA and mean of ROE are $0.8 \%$ and $8.9 \%$, respectively. The standard deviations are $0.7 \%$ and $6.7 \%$, respectively. In general, commercial banks earn annual profits, but the average return on assets is not high, and the efficiency of equity is better than ROA. Capital adequacy ratios (CAR) have an average of $15.73 \%$ with a standard deviation of $8.42 \%$, peak at $55.00 \%$ by Viet Capital bank in 2008 and bottom at $6.66 \%$ by BID bank in 2008 . The average loan loss provision (PROV) is $-1.3 \%$, and the volatility compared to the average is relatively low, reaching $0.06 \%$. On average, the liquidity and capital for this sample dataset constitute $4.81 \%$ and $10.63 \%$ of total assets, respectively. Finally, the macroeconomic variables, the average GDP growth rate is $6.00 \%$ and $0.52 \%$ of the standard deviation. Meanwhile, the inflation rate (INF) has the lowest value of $0.63 \%$ in 2015 and the highest of $23.12 \%$ in 2008 . INF fluctuates at around $6.83 \%$ of the standard deviation, and the average value is $8.43 \%$.

Table 2. The summary of variables used in the regression

\begin{tabular}{lccccc}
\hline Variables & Obs & Mean & Std. Dev. & Min & Max \\
\hline NPLs & 250 & 0.0231 & 0.0153 & 0.0000 & 0.1140 \\
Z-score & 250 & 2.1604 & 1.7146 & -1.2125 & 7.8311 \\
LnTA & 250 & 0.1064 & 0.0740 & 0.0346 & 0.8083 \\
BC & 250 & 32.1095 & 1.3417 & 27.8779 & 34.723 \\
ROA & 0.0089 & 0.0072 & -0.01281 & 0.0595 \\
ROE & 250 & 0.0889 & 0.0667 & -0.0827 & 0.3628 \\
LIQ_A & 250 & 0.04810 & 0.0403 & 0.0018 & 0.3143 \\
LLPs & 250 & -0.0127 & 0.0059 & -0.0396 & -0.0010 \\
CAR & 250 & 0.1572 & 0.0842 & 0.0662 & 0.555 \\
INF & 250 & 0.08434 & 0.0683 & 0.0063 & 0.2312 \\
GDP & 250 & 0.0607 & 0.0052 & 0.0525 & 0.0681 \\
\hline
\end{tabular}

\subsection{Panel Regression}

In this study, the independent variables data are used to determine the relationship between bank size, bank capital, loan loss provision, return on asset, return on equity, liquidity, capital adequacy requirements, inflation, and GDP growth rate. Table 3 reports the correlation coefficient between the used variables in this study. The results show that the bank variables in the model not to be highly correlated. If the correlation coefficients are greater than 0.8 , there may be a multicollinearity issue. The value of the coefficients has been taken the absolute, and the data ranges from 0.007 to 0.7403 . This implies that multicollinearity is on no account a vital issue in the research model. To be more particular, we will take one more step to test the multicollinearity in regression by Variance Inflation Factors (VIF).

Table 3. Correlation test of selected variables

\begin{tabular}{|c|c|c|c|c|c|c|c|c|c|}
\hline & LnTA & $\mathrm{BC}$ & ROA & ROE & LIQ_A & LLPs & CAR & $\mathrm{INF}$ & GDP \\
\hline LnTA & 1.0000 & & & & & & & & \\
\hline $\mathrm{BC}$ & -0.6554 & 1.0000 & & & & & & & \\
\hline ROA & -0.1956 & 0.3698 & 1.0000 & & & & & & \\
\hline ROE & 0.2757 & -0.2237 & 0.6757 & 1.0000 & & & & & \\
\hline LIQ_A & -0.1968 & 0.0708 & -0.0152 & -0.1169 & 1.0000 & & & & \\
\hline LLPs & -0.4304 & 0.3012 & 0.0680 & -0.1412 & 0.0762 & 1.0000 & & & \\
\hline CAR & -0.5557 & 0.7403 & 0.0977 & -0.3049 & 0.0204 & 0.2407 & 1.0000 & & \\
\hline INF & -0.3089 & 0.3164 & 0.3795 & 0.2706 & 0.1598 & -0.0070 & 0.2499 & 1.0000 & \\
\hline GDP & 0.1210 & -0.0672 & -0.0461 & 0.0226 & -0.1620 & 0.1209 & -0.0273 & -0.0423 & 1.0000 \\
\hline
\end{tabular}

According to the result in Table 4, the average VIF is 2.49, and VIF values range from 1.08 to 4.28 . All VIF values are less than 10 , so it is possible to conclude that there are not any multicollinearity issues among the independent variables. 
Table 4. VIF test

\begin{tabular}{lll}
\hline Variable & VIF & 1/VIF \\
\hline BC & 4.28 & 0.233772 \\
ROA & 4.18 & 0.239464 \\
ROE & 4.09 & 0.244260 \\
CAR & 2.50 & 0.400049 \\
LnTA & 2.33 & 0.428304 \\
INF & 1.46 & 0.684231 \\
LLPs & 1.32 & 0.756392 \\
LIQ_A & 1.12 & 0.892565 \\
GDP & 1.08 & 0.924733 \\
Mean VIF & 2.49 & \\
\hline
\end{tabular}

Next, we use panel data regression with three models: Pooled OLS, Fixed Effects Model (FEM), and Random Effects Model (REM) to recommend the most suitable model in this research. Table 5 shows the outcomes of the comparison of the three models.

Table 5. Comparing between pooled OLS, fixed effect model and random effect model

\begin{tabular}{|c|c|c|c|c|}
\hline \multirow[b]{2}{*}{ Model } & \multirow[b]{2}{*}{ Test } & \multicolumn{2}{|c|}{ NPLs } & \multirow[b]{2}{*}{ Result } \\
\hline & & F test & P-value & \\
\hline Pooled OLS and FEM & F test & $\mathrm{F}(24,216)=72.35$ & Prob $>F=0.0000$ & FEM \\
\hline Pooled OLS and REM & $\mathrm{LM}(*)$ & $\operatorname{chibar} 2(01)=5.13$ & Prob $>$ chibar $2=0.0118$ & REM \\
\hline \multirow[t]{2}{*}{ FEM and REM } & Hausman & $\operatorname{chi} 2(9)=17.28$ & Prob $>$ chi $2=0.0445$ & FEM \\
\hline & & \multicolumn{2}{|c|}{ Z-score } & \\
\hline Model & Test & $F$ test & P-value & Result \\
\hline Pooled OLS and FEM & F test & $F(24,216)=72.35$ & Prob $>F=0.0000$ & FEM \\
\hline Pooled OLS and REM & $\mathrm{LM}(*)$ & $\mathrm{F}(24,216)=72.35$ & Prob $>F=0.0000$ & REM \\
\hline FEM and REM & Hausman & $\operatorname{chi} 2(9)=17.20$ & Prob $>$ chi $2=0.0456$ & FEM \\
\hline
\end{tabular}

(*) LM: The Lagrange Multiplier Test.

F-test compares the pooled OLS and Fixed Effects Model. The p-value is lower than 0.05 (p-value $=0.000$ ), the null hypothesis is rejected, and FEM outperforms pooled OLS. Moreover, the Lagrange Multiplier test (Breusch-Pagan Lagrange multiplier - LM) to select between the pooled OLS and REM, which has the result of p-value also equal to 0.000 , referring to the random-effects model to be better than the pooled OLS. Finally, the Hausman test examines and chooses a more suitable regression model between fixed and random effects. The null hypothesis of this test is that the favoured model as random effects. There is no doubt that the p-value in models with dependent variables (NPLs and Z-score) is less than 0.05. It means FEM is the most suitable model.

We use Breusch-Pagan to test for heteroskedasticity of errors in regression. In this test, the null hypothesis is constant variance. The result is presented in appendix B. With this test, statistics have a p-value below an appropriate threshold ( $\mathrm{p}$-value < 0.05), then the null hypothesis is rejected. In a nutshell, this model has heteroskedasticity.

This research uses the Wooldridge test for autocorrelation in panel data. Based on the null hypothesis in the test, it is presumed that there is no autocorrelation. The outcome of this test is presented in appendix C. It can clearly be seen that the p-values are lower than 0.05 , which can refer to as the existing phenomenon of serial correlation.

Since the problem of heteroscedasticity and autocorrelation exist in the regress model, we use robust regression models with Driscoll-Kraay standard errors. The result is reported as follows: 
Table 8. Fixed effects with robust errors

\begin{tabular}{lllll}
\hline \multirow{2}{*}{ Variables } & \multicolumn{3}{c}{ NPLs } & Z-score \\
\cline { 2 - 5 } LnTA & Estimate & p-value & Estimate & p-value \\
BC & 0.000813 & 0.287 & $-0.301^{* * *}$ & 0.000 \\
ROA & $0.0129^{*}$ & 0.075 & $0.899^{* *}$ & 0.001 \\
ROE & -0.0846 & 0.378 & $62.44^{* * *}$ & 0.000 \\
LIQ_A & $-0.0484^{* * *}$ & 0.000 & $9.140^{* * *}$ & 0.000 \\
LLPs & -0.0193 & 0.158 & -0.329 & 0.619 \\
CAR & $-1.928^{* * *}$ & 0.000 & $-11.95^{* * *}$ & 0.008 \\
INF & 0.00936 & 0.103 & $0.484^{* * *}$ & 0.001 \\
GDP & $0.0376^{* * *}$ & 0.000 & -0.0819 & 0.770 \\
\hline
\end{tabular}

\section{Discussion}

Bank size is negatively correlated to Z-score at significance levels of $1 \%$. The result implies that the insolvency risk will be higher if the commercial banks have a larger size. The finding can be explained as the banks with a big asset will venture into the decisions, portfolio, and investments or expand product by using more leverage. That is consistent with earlier research such as Boyd and Runkle (1993), Demsetz and Strahan (1997), Kane (2010), and Babanskiy (2012).

The leverage ratio is considered as a buffer in the banking sector against losses. The research results illustrate that bank capitalization (BC) positively correlates with Z-score at a $1 \%$ significance level. Increasing capital can reduce bank risks, and it is consistent with the previous studies by Diamond (1984), Rahman, Ibrahim, Meera (2009), Tan and Floros (2013), and Morrison and White (2005). Diamond (2000) found that increased equity would reduce bank risks. Rahman, Ibrahim, and Meera (2009) suggested that the risk is lower when banks have higher capital, and banking supervision will improve. It also explains that banks will have a safer buffer for their capital when they increase shareholder's equity, so the banks expand their investments and introduce new business products and use the amount of capital to combat bank risk. The results also indicate a positive relationship between the ROA, ROE and Z-score at a significance level of $1 \%$. So, the more banks have profits, the lower risk they will face. Return on equity (ROE) is negatively related to non-performing loans (NPLs). Based on this result, if the banks increase ROE, they become riskier because they provide more loans, leading to higher NPL.

Results analysis shows that the loan loss provision (LLPs) negatively impacts Z-score and NPLs at a 5\% significance level. It means that if banks make more provisions for credit risk, the non-performing loan ratio will reduce. More loan loss provision suggests banks need to have more prudent policies on loans to customers. Banks need to pay more attention to control loans, which can assist the banks in determining the issue and figuring out a way to solve it as soon as possible. Therefore, it can be possible to reduce the non-performing loans ratio in the banks. This result is also explained because borrowers are of creditworthiness. The banks will decline bad debts, leading to non-performing loans related positively to banks' liquidity because banks have the potential to pay the interest, deposit money or sudden withdrawal of deposits.

Capital adequacy ratio (CAR) is a virtually necessary standard to reflect truly a bank's financial health. The result indicates that CAR is related positively to Z-score at a significant level of $1 \%$. Higher CAR leads to lower insolvency risk. Given the characteristics of the capital adequacy ratio, banks make up for their risk when this ratio crosses the SBV's threshold. Then, the bank will play an important role in improving their lend without customer screening, leading to credit risk. The relationship is similar to the study of Shrieves and Dahl (1992), Rime (2001), Altunbas, Carbo, Gardener, and Molyneux (2007), and Lee and Chih (2013).

From the table results, the effect of the inflation rate (INF) remains positive on bank credit risk. The research results imply that when the inflation rate is higher, banks will take more risk and are consistent with the previous results of Nkusu (2011), Gunsel (2012), Badar and Javid (2013) and Mohamed (2015). In economics, the higher rate of inflation adversely affects the ability to pay borrowers' loans because of changes in policies to combat inflation, which worsens the portfolio quality and increases banks' credit risks. Moreover, when the inflation rate increases, the banks cannot control and assess the truth value of borrowers' credit ratings.

This study suggests that there is an opposite relation between GDP growth and credit risk, indicating that when GDP rises, credit risk and insolvency risk will decrease. The possible explanation for this result is that an 
economic growth rate will positively correlate with income, leading to improved ability financial conditions for borrowers and thus reducing the banks' bad debt ratio and insolvency risk.

\section{Conclusion}

In recent years, the complicated movements of risks always built a significant challenge for the banking sector all over the world and in Vietnam. Banks are affected by a myriad of variables, which vary from internal factors to external factors. The identification of risk factors is the top priority for banks.

This research examines the fundamental characteristics of commercial banks that affect risk by using a sample collection from the annual reports of Vietnamese commercial banks over the period of 10 years (2008-2017). We use the regression model with Driscoll-Kraay standard errors to examine the determinants of bank risk in Vietnam. The research results illustrate bank risk factors, including internal, capital regulatory, and macroeconomic variables. For internal variables, size, ROA, ROE, LLP affect bank risk. The capital adequacy ratio represents capital regulatory; if this ratio increases, the banks will decrease insolvency risk. Besides, the GDP growth rate has a negative relationship with credit risk and insolvency risk. We also find that inflation has a significant positive correlation with credit risk. Moreover, there is no relation between liquidity and bank risk in this research.

From the obtained results, we have some recommendations for controlling the risks of Vietnamese commercial banks. The global economic crisis affects Vietnam economy, but it is still necessary to maintain economic growth with government policies. Economic growth can create more profits for investors or individual and organizational income, improving the borrower's debts and solvency, thereby declining non-performing loans (NPLs). CAR helps the bank reduce risk, so banks should have enough capital adequacy. Moreover, bank capitalization negatively impacts risk. Banks need to have strategies to increase equity to expand operations and create more new products to compete with other banks. If banks have more capital, they not only improve financial capacity but also prevent the risk.

\section{References}

Adamgbo, S., \& Adolphus, J. T. (2019). The Effect of Capital Adequacy on Credit Risk Management among Commercial Banks in Nigeria; Within the Basel Capital Adequacy Framework. International Journal of Contemporary Research and Review, 10(7). https://doi.org/10.15520/ijcrr.v10i07.714

Anthony, S., Elizabeth, S., \& Nickolaos, G. T. (1990). Ownership Structure, Deregulation, and Bank Risk Taking. Journal of Finance, 45(2), 643-54. https://doi.org/10.1111/j.1540-6261.1990.tb03709.x

Atoi, N. V. (2018). Non-performing loan and its effects on banking stability: Evidence from national and international licensed banks in Nigeria. CBN Journal of Applied Statistics, 9(2), 43-74. https://doi.org/10.33429/Cjas.09218.3/6

Bertrand, R. (2001). Capital requirements and bank behaviours: empirical evidence for Switzerland. Journal of Banking and Finance, 25(4), 789-805. https://doi.org/10.1016/S0378-4266(00)00105-9

Buthiena, K., Mishiel, S. S., \& Ramadan, E. (2019). Nonlinear association between controlling shareholders and leverage: evidence from Jordan. Afro-Asian Journal of Finance and Accounting, 9(2), 193-212. https://doi.org/10.1504/AAJFA.2019.099482

Chiaramonte, L., Liu, H., Poli, F., \& Zhou, M. (2016). How accurately can Z-score predict bank failure? Financial Markets, Institutions \& Instruments, 25(5), 333-360. https://doi.org/10.1111/fmii.12077

Demirguc-Kunt, A., \& Huizinga, H. (2000). Financial structure and bank profitability. World Bank Mimeo. https://doi.org/10.1596/1813-9450-2430

El-Khoury, R. (2020). Regulation, bank capital, and bank risk: Evidence from the Lebanese banking industry. Journal of Banking Regulation, 21, 241-255. https://doi.org/10.1057/s41261-019-00111-2

Ha, N., \& Quyen, P. (2018). The Impact of Funding Liquidity on Risk-taking Behaviour of Vietnamese Banks: Approaching by Z-Score Measure. International Journal of Economics and Financial Issues, 8(3), 29-35.

Haq, M., \& Heaney, R. (2012). Factors determining European bank risk. Journal of International Financial Market Institutions, and Money, 22, 696-718. https://doi.org/10.1016/j.intfin.2012.04.003

Hien, N., \& Giang, C. (2020). Competition, risk and profitability in banking system - Evidence from Vietnam. The Singapore Economic Review, 65(6). https://doi.org/10.1142/S0217590820500137

Homölle, S. (2008). Does transparency restrict banks' risk taking? Working Paper. 
Jensen, M., \& Meckling, W. (1976). Theory of the Firm: Managerial Behavior, Agency Costs and Ownership Structure. Journal of Finance Economics, 3(4), 305-360. https://doi.org/10.1016/0304-405X(76)90026-X

Jimenez, G., \& Jesus, S. (2005). Credit cycles, credit risk, and prudential regulation. Banco de Espana, January. https://www.ijcb.org/journal/ijcb06q2a3.htm

Kadri, M., \& David, G. M. (2009). Explaining bank distress in Eastern European transition economies. Journal of Banking \& Finance, 33(2), 244-253. https://doi.org/10.1016/j.jbankfin.2008.07.016

Kadri, M., \& David, M. (2009). Explaining bank distress in Eastern European transition economies. Journal of Banking \& Financ, 33(2), 244-253. https://doi.org/10.1016/j.jbankfin.2008.07.016

Kobia, A. M. (2018). Effect of inflation rate on profitability of commercialbanks in Kenya. Rerieved from http://erepository.uonbi.ac.ke/bitstream/handle/11295/105453/Kobia

Laeven, L., Ratnovski, L., \& Tong, H. (2014). Bank Size and Systemic Risk. https://doi.org/10.2139/ssrn.2437729

Louzis, D. P., Vouldis, A. T., \& Metaxas, V. L. (2012). Macroeconomic and bank-specific determinants of non-performing loans in Greece: A comparative study of mortgage, business and consumer loan portfolios. Journal of Banking \& Finance, 36(4), 1012-1027. https://doi.org/10.1016/j.jbankfin.2011.10.012

Martynova, N., Ratnovski, L., \& Vlahu, R. (2015). Bank Profitability and Risk-Taking. International Monetary Fund. IMF Working Paper. https://doi.org/10.5089/9781513517582.001

Maseke, B. F., \& Swartz, E. M. (2020). Risk Management Impact on Non-Performing Loans and Profitability in the Namibian Banking Sector. Open Access Library Journal, 8, 66943. https://doi.org/10.4236/oalib.1106943

Miller, S. M., \& Noulas, A. (1997). Portfolio mix and large bank profitability in the USA. Applied Economics, 29(4), 505-512. https://doi.org/10.1080/000368497326994

Mongid, A., Tahir, I. Z., \& Haron, S. (2012). The Relationship between Inefficiency, Risk and Capital: Evidence from Commercial Banks in ASEAN. International Journal of Economics and Management, 6(1), 58-74. http://www.ijem.upm.edu.my/vol6no1/bab04.pdf

Morrison, A. D., \& White, L. (2005). Crisis and capital requirements in banking. American Economic Review. https://doi.org/10.1111/j.1540-6261.1990.tb03709.x

Muhammad, S. K., Harald, S., \& Eliza, W. (2017). Funding liquidity and bank risk taking. Journal of Banking \& Finance, 82(C), 203-216. https://doi.org/10.1016/j.jbankfin.2016.09.005

Myra, V. De L. (2020). The impact of credit risk and macroeconomic factors on profitability: The case of the ASEAN banks. Banks and Bank Systems, 15(1), 21-29. https://doi.org/10.21511/bbs.15(1).2020.03

Noman, A. H. M., Pervin, S., Chowdhury, M. M., \& Banna, H. (2015). The Effect of Credit Risk on the Banking Profitability: A Case on Bangladesh. Global Journal of Management and Business Research: C Finance, 15(3), 41-48. https://doi.org/10.20525/ijfbs.v9i3.874

Pasiouras, F., \& Kosmidou, K. (2007). Factors influencing the profitability of domestic and foreign commercial banks in the European Union. International Business and Finance, 21, 222-237. https://doi.org/10.1016/j.ribaf.2006.03.007

Patrick, O. N., Ikenna, J. E., \& Ekemezie, L. I. (2017). The Impact of Credit Risk Management on Deposit Money Banks Performance in Nigeria. Nigerian Journal of Management Sciences, 6(1).

Roy, A. D. (1952). Safety First and the Holding of Assets. Econometrica, 20, 431-449. https://doi.org/10.2307/1907413

Salas, V., \& Saurina, J. (2002). Credit risk in two institutional regimes: Spanish commercial and savings banks. Journal of Financial Services Research, 22, 203-224. https://doi.org/10.1023/A:1019781109676

Sanjai, B., Brian, J. B., \& Jun, L. (2012). Size, Leverage, and Risk-Taking of Financial Institutions. Journal of Banking and Finance, 59. https://doi.org/10.1016/j.jbankfin.2015.06.018

Siddika, A., \& Haron, R. (2020). Capital regulation and ownership structure on bank risk. Journal of Financial Regulation and Compliance, 28(1), 39-56. https://doi.org/10.1108/JFRC-02-2019-0015

Tan, Y. (2016). The impacts of risk and competition on bank profitability in China. Journal of International Financial Markets, Institutions and Money, 40, 85-110. https://doi.org/10.1016/j.intfin.2015.09.003

Tan, Y., \& Floros, C. (2013). Risk, Capital and efficiency in Chinese banking. Journal of International Financial 
Markets, Institutions and Money, 26, 378-393. https://doi.org/10.1016/j.intfin.2013.07.009

Zhichao, Z., Li, X., Xiangyun, L., \& Zhuang, Z. (2014). Determinants of financial distress in u.s. large bank holding companies. Contemporary Economic Policy: A Journal of Western Economic Association International, 34(2), 250-267. https://doi.org/10.1111/coep.12105

\section{Appendix A}

\section{The List Vietnamese Commercial Banks}

\begin{tabular}{ccc}
\hline No. & Bank & Abbreviation \\
\hline 1 & An Binh Bank & ABBANK \\
2 & Asia Commercial Joint Stock Bank & ACB \\
3 & Vietnam Bank for Agriculture and Rural Development & BID \\
4 & JSC Bank for Investment and Development of Vietnam & CTG \\
5 & Vietnam Joint Stock Commercial Bank for Industry and Trade & EIB \\
6 & Vietnam Joint Stock Commercial Vietnam Export Import Bank & HDBank \\
7 & Ho Chi Minh City Housing Development Bank & KienLongBank \\
8 & Kien Long Commercial Joint Stock Bank & LPB \\
9 & Joint stock commercial Lien Viet postal bank & MB \\
10 & Military Commercial Joint Stock Bank & MSB \\
11 & Vietnam Maritime Joint - Stock Commercial Bank & Nam A Bank \\
12 & Nam A commercial Join Stock Bank & NCB \\
13 & National Citizen Bank & PG Bank \\
14 & Joint Stock Commercia Petrolimex Bank & SCB \\
15 & Saigon Commercial Bank & SeABank \\
16 & Southeast Asia Commercial Joint Stock Bank & SGB \\
17 & Saigon Thuong Tin Commercial Joint Stock Bank & SHB \\
18 & Saigon - Hanoi Commercial Joint Stock Bank & STB \\
19 & Sai Gon Thuong Tin Commercial Joint Stock Bank & TCB \\
20 & VietNam Technological and Commercial Joint Stock Bank & VCB \\
21 & Joint Stock Commercial Bank for Foreign Trade of Vietnam & VIB \\
22 & Vietnam International and Commercial Joint Stock Bank & VietBank \\
25 & Vietnam Thuong Tin Commercial Joint Stock Bank & VPBank \\
\hline
\end{tabular}

\section{Appendix B}

Table B1. Heteroskedasticity test

\begin{tabular}{ccccc}
\hline & Test & F test & P-value & Result \\
\hline NPLs & Breusch-Pagan & Chi2 $(1)=79.47$ & 0.0000 & Heteroskedasticity \\
Z-score & Breusch-Pagan & Chi2 $(1)=96.59$ & 0.0000 & Heteroskedasticity \\
\hline
\end{tabular}

Table B2. Autocorrelation test

\begin{tabular}{ccccc}
\hline & Test & F test & P-value & Result \\
\hline NPLs & Wooldridge test & $\mathrm{F}(1,24)=10.021$ & 0.0042 & Autocorrelation \\
Z-score & Wooldridge test & $\mathrm{F}(1,24)=4.441$ & 0.0457 & Autocorrelation \\
\hline
\end{tabular}

\section{Copyrights}

Copyright for this article is retained by the author(s), with first publication rights granted to the journal.

This is an open-access article distributed under the terms and conditions of the Creative Commons Attribution license (http://creativecommons.org/licenses/by/4.0/). 